\title{
Penggantian Wali Nasab oleh Wali Hakim menurut Intruksi Presiden Nomor 1 Tahun 1991
}

\author{
Ahmad Nabil Atoilah \\ Institut Agama Islam Darussalam (IAID) Ciamis, Jawa Barat \\ Email: gusnabi.ahmad@gmail.com \\ Ahmad Kamal \\ Institut Agama Islam Darussalam (IAID) Ciamis, Jawa Barat
}

\begin{abstract}
ABSTRAK
Kompilasi Hukum Islam (KHI) pasal 19 menyatakan bahwa "wali nikah dalam perkawinan merupakan rukun yang harus dipenuhi bagi calon mempelai wanita yang bertindak untuk menikahkannya". Wali nikah terdiri dari dua, yaitu wali nasab dan wali hakim. Wali nasab merupakan wali nikah yang didasarkan pada hubungan darah atau kekerabatan dengan mempelai wanita dari pihak ayah kandung. Sedangkan wali hakim adalah wali nikah yang ditunjuk oleh Menteri Agama atau pejabat yang ditunjuk olehnya, yang diberi hak dan kewenangan untuk bertindak sebagai wali. Mengenai wali nasab, bilamana wali tersebut tidak ada atau tidak mau menikahkan anak gadis di bawah perwaliannya maka hak wali nikahnya jatuh kepada wali hakim.
\end{abstract}

\begin{abstract}
The compilation of Islamic Law (KHI) article 19 states that "marriage guardian in marriage is a pillar that must be met for the prospective bride who acts to marry her". The marriage guardian consists of two, namely the guardian of the nasab and the judge's guardian. Wali nasab is a marriage guardian based on blood relation or kinship with the bride of the father's side. While the judge's guardian is a marriage guardian appointed by the Minister of Religious Affairs or an official appointed by him, who is given the right and authority to act as a guardian. Regarding the guardian, if the guardian is not present or does not want to marry a girl under her guardianship, her marriage guardian right falls to the judge's guardian.
\end{abstract}

Keywords: marriage guardian, compilation of Islamic law (KHI), wali nasab.

\section{PENDAHULUAN}

Wali nikah adalah orang yang menikahkan seorang wanita dengan seorang pria. Keadaan ini dikarenakan wali nikah dalam hukum 
perkawinan Islam merupakan rukun yang harus dipenuhi oleh calon mempelai wanita, sebagai pihak yang harus menikahkan wanita tersebut. Hukum menikah tanpa adanya wali nikah dapat berakibat tidak sahnya perkawinan tersebut, karena rukun nikahnya tidak terpenuhi (Zainuddin, 2012: 11).

Wali nikah selain merupakan rukun nikah, juga merupakan syarat sah pernikahan seorang perempuan, tanpa wali pernikahan menjadi tidak sah. Oleh karena itu ketika seorang wanita ingin melaksanakan pernikahan maka seorang wali tidak boleh mencegah atau menghalanginya, karena mengingat betapa pentingnya wali dalam pernikahan (Al-Bajuri, 2: 101).

Demikian penting seorang wali dalam pernikahan, namun tidak semua orang dapat menjadi wali. Terkait hak perwalian dalam pernikahan, wali ditunjuk berdasarkan urutan tertibnya, adapun tertib wali tersebut yaitu, "Ayah, kakek dari ayah, saudara laki-laki seayah dan seibu, saudara laki-laki seayah, anak laki-laki dari saudara laki-laki seayah dan seibu, anak laki-laki dari saudara laki-laki seayah, paman, anak paman, dan hakim" (Taqiyudin, t.t.: 43 ).

Berdasarkan tertib urutan wali nikah, apabila wali pertama tidak ada, hendaklah diambil wali yang kedua, jika wali kedua tidak ada maka dari wali ketiga, begitulah seterusnya mengikuti tertib wali yang ada. Sebagaimana tertera pada pasal 22 Kompilasi Hukum Islam, bahwa "Apabila wali nikah yang paling berhak, urutannya tidak memenuhi syarat sebagai wali nikah atau oleh karena wali nikah itu menderita tuna wicara, tuna rungu atau sudah udzur, maka hak menjadi wali bergeser kepada wali nikah yang lain menurut derajat berikutnya" (Anonimous, 2014: 330).

\section{KAJIAN TEORETIK}

\section{Konsep Nikah}

Menurut Kamus Besar Bahasa Indonesia (KBBI, t.t.:373), bahwa kata nikah berarti "ikatan (akad) perkawinan yang dilakukan sesuai dengan ketentuan hukum dan ajaran agama". Seiring dengan hal itu Rasyid (2008: 17) menyatakan pernikahan berasal dari kata dasar nikah, kata nikah memiliki persamaan dengan kata kawin.. Menurut istilah syarak, nikah itu berarti melakukan suatu akad atau perjanjian untuk mengikatkan diri antara seorang laki-laki dan seorang perempuan yang bertujuan untuk menghalalkan hubungan kelamin antara keduanya dengan dasar suka rela demi terwujudnya keluarga bahagia yang diridhoi oleh Allah Nikah adalah fitrah yang berarti sifat asal dan pembawaan manusia sebagai makhluk Allah

Konsep Wali Nikah 
Menurut Saebani (2010: 192), secara bahasa kata "wali" berarti orang yang menurut hukum (agama, adat) diserahi kewajiban mengurus anak yatim serta hartanya selama anak itu belum dewasa. Adapun kata "perwalian" berarti segala sesuatu mengenai urusan wali; pemeliharaan dan pengawasan anak yatim dan hartanya.

Wali dalam pernikahan memegang peranan sangat penting, karena wali yang menjadi pihak pertama dalam mengucapkan akad nikah, dalam arti lain wali yang mengucapkan ijab nikah kepada calon mempelai pria yang kemudian calon mempelai pria tersebut mengucapkan qabul nikah, dan dengan akad inilah inti dari suatu pernikahan sah atau tidak.

Mengenai perwalian, dinyatakan dalam pasal 19 KHI, sebagai berikut "Wali nikah dalam perkawinan merupakan rukun yang harus dipenuhi bagi calon mempelai wanita yang bertindak untuk menikahkannya" (Anonimous, 2007:11).

Saebani (2001:237) mengatakan wali bertanggung jawab atas sahnya akad pernikahan, oleh karena itu, wali harus memiliki beberapa sifat berikut: Pertama, Islam. orang yang tidak beragama Islam tidak sah menjadi wali. Firman Allah

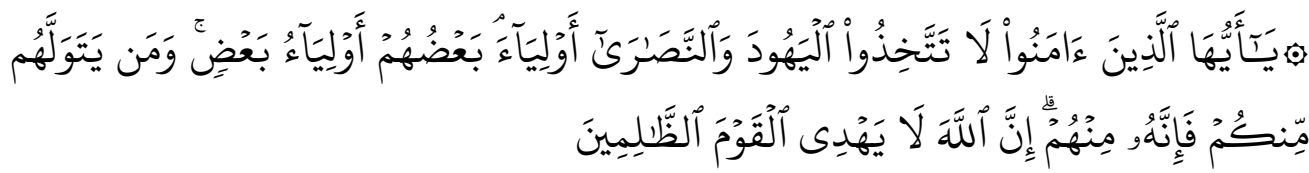

Hai orang-orang yang beriman, janganlah kamu mengambil orangorang Yahudi dan Nasrani menjadi pemimpin-pemimpin $(\mathrm{mu})$, sebahagian mereka adalah pemimpin bagi sebahagian yang lain. Barangsiapa diantara kamu mengambil mereka menjadi pemimpin, maka sesungguhnya orang itu termasuk golongan mereka. Sesungguhnya Allah tidak memberi petunjuk kepada orang-orang yang zalim (Q.S. Al-Maidah, 5:51).

Syarat untuk bisa menjadi wali adalah balig (sudah berumur sedikitnya 15 tahun), berakal, merdeka, laki-laki, dan adil.

Terdapat beberapa macam wali dalam pernikahan, yaitu antara lain Wali Nasab. Rofiq (1997:32) mengatakan bahwa wali adalah orang yang berhak atau berwenang untuk melakukan suatu perbuatan hukum bagi yang diwakilinya untuk kepentingan dan atas nama yang diwakili. Sedangkan wali dalam pernikahan adalah orang yang berhak menikahkan seorang perempuan yang diurusnya (maula) apabila ia (wali) sanggup bertindak sebagai wali. Apabila karena suatu hal ia tidak dapat bertindak sebagai wali maka hak kewaliannya berpindah kepada orang lain. Firman Allah: 


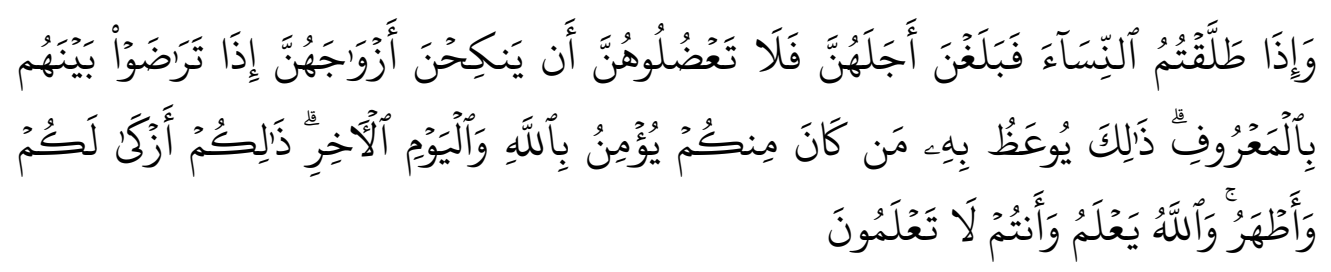

“Apabila kamu mentalak isteri-isterimu, lalu habis masa iddahnya, Maka janganlah kamu (para wali) menghalangi mereka kawin lagi dengan bakal suaminya, apabila telah terdapat kerelaan di antara mereka dengan cara yang ma'ruf" (Q.S. al Baqarah, 2:232).

Asqalani (t.t.:211) menyatakan bahwa Rasulullah SAW. bersabda:

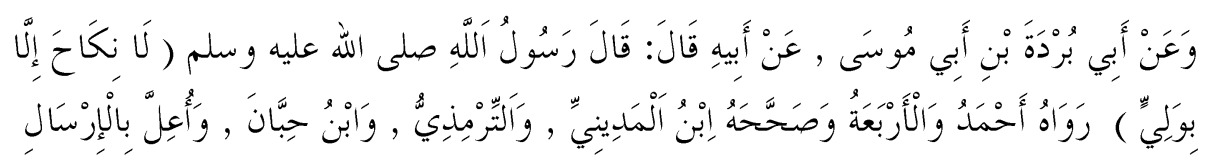

“Dari Abu Burdah Ibnu Abu Musa, dari ayahnya Radliyallaahu 'anhu bahwa Rasulullah Shallallaahu 'alaihi wa Sallam bersabda: "Tidak sah nikah kecuali dengan wali." Riwayat Ahmad dan Imam Empat. Hadits shahih menurut Ibnu al-Madiny, Tirmidzi, dan Ibnu Hibban. Sebagian menilainya hadits mursal" (Asqalany, 2008:1008).

Berkenaan dengan dalil nash diatas, Saifullah (2005:11) menegaskan pula bahwa dalam pasal 19 KHI menyatakan "Wali nikah dalam perkawinan merupakan rukun yang harus dipenuhi bagi calon mempelai wanita yang bertindak untuk menikahkannya". Kemudian pasal 20 bahwa, "Yang bertindak sebagai wali nikah adalah seorang laki-laki yang memenuhi syarat hukum Islam, yakni muslim, akil dan baligh".

Imam Taqiyudin dalam Kifayatul Akhyar menyatakan, bahwa wali dan dua orang saksi membutuhkan kepada enam syarat, yaitu: Islam, baligh, mempunyai akal sempurna, merdeka dari perbudakan, laki-laki dan bersifat adil kecuali sesungguhnya tidak membutuhkan nikahnya wanita dzimmi pada wali yang muslim dan tidak pula nikahnya hamba sahaya perempuan kepada adil tuannya. (Taqiyudin, t.t. juz 2: 40-41)

Berkaitan dengan syarat wali yaitu Islam, maka orang yang tidak beragama Islam tidak sah menjadi wali ataupun saksi. Firman Allah:

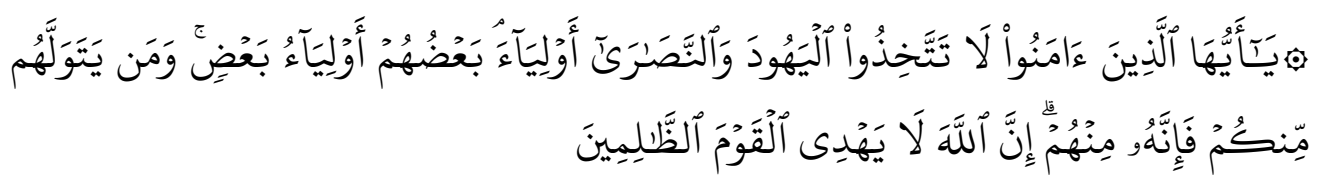

Hai orang-orang yang beriman, janganlah kamu mengambil orangorang Yahudi dan Nasrani menjadi pemimpin-pemimpin(mu); sebahagian mereka adalah pemimpin bagi sebahagian yang lain. Barangsiapa diantara kamu mengambil mereka menjadi pemimpin, 
Maka Sesungguhnya orang itu termasuk golongan mereka. Sesungguhnya Allah tidak memberi petunjuk kepada orang-orang yang zhalim (Q.S. Al Maidah, 5:51).

Taqiyuddin (t.t.: 41) menyatakan bahwa ayat diatas adalah perintah Allah yang berisikan salah satu petunjuk tentang tidak bolehnya seorang wanita muslim yang akan menikah disertai walinya yang kafir, karena "Seorang kafir tidak akan bisa menjadi penolong, maka tidak boleh dia menjadi wali".

Penting seorang wali dalam pernikahan, namun tidak semua orang dapat menjadi wali. Terkait hak perwalian dalam pernikahan, wali ditunjuk berdasarkan urutan tertibnya, adapun tertib wali tersebut yaitu ayah, kakek dari ayah, saudara laki-laki seayah dan seibu, saudara laki-laki seayah, anak laki-laki dari saudara laki-laki seayah dan seibu, anak laki-laki dari saudara laki-laki seayah, paman, anak paman, hakim.

Hak Perwalian Wali Hakim dalam Hukum Islam dan Kompilasi Hukum Islam (KHI)

1) Hak Perwalian dalam Kompilasi Hukum Islam

Dalam buku Kompilasi Hukum Islam, mengenai perwalian dapat dirinci sebagai berikut:

Dalam buku I pasal 19,20,21,22 dan 23 berkenaan dengan wali nikah, disebutkan: Pasal 19: Wali nikah dalam pernikahan merupakan rukun yang harus dipenuhi bagi calon mempelai wanita yang bertindak menikahkannya. Pasal 20: (1) yang bertindak sebagai wali nikah ialah seorang laki-laki yang memenuhi syarat hukum Islam yakni muslim, aqil dan baligh. (2) wali nikah terdiri dari: a. Wali nasab, b. Wali hakim. Pasal 21: (1) wali nasab terdiri dari empat kelompok dalam urutan kedudukan; kelompok yang satu didahulukan dari kelompok yang lain sesuai erat tidaknya susunan kekerabatan dengan calon mempelai. (2) apabila dalam satu kelompok wali nikah terdapat beberapa orang yang sama-sama berhak menjadi wali, maka yang paling berhak menjadi wali ialah yang lebih dekat derajat kekerabatannya dengan calon mempelai wanita. (3) apabila dalam satu kelompok sama derajat kekerabatnnya, maka yang paling berhak menjadi wali nikah ialah kerabat kandung dari kerabat yang hanya seayah. (4) apabila dalam satu kelompok derjat kekerabatannya sama yakni samasama derajat kandung atau sama-sama derajat kerabat ayah, mereka samasama behak menjadi wali nikahdengan mengutamakan yang lebih tua dan memenuhi syarat-syarat wali. Pasal 22: apabila wali nikah yang paling berhak urutannya tidak memenuhi syarat-syarat sebagai wali nikah atau oleh karena wali nikah itu menderita tuna wicara, tunarungu atau sudah udzur, maka hak menjadi wali bergeser kepada wali nikah yang lain menurut derajat berikutnya. Pasal 23: (1) wali hakim baru dapat bertindak 
sebagai wali nikah apabila wali nasab tidak ada atau tidak mungkin menghadirkannya atau tidak diketahui tempat tinggalnya atau ghoib atau adhol atau enggan. (2) dalam hal wali adhol atau enggan, maka wali hakim baru bertindak sebagai wali nikah setelah ada putusan Pengadilan Agama tentang wali tersebut. (Anonimous, 2003:233)

Tentang hak perwalian dalam hukum Islam disebutkan dalam Pasal 23 ayat $1 \mathrm{KHI}$ diatas menyatakan sebab-sebab atau alasan yang dapat menjadi landasan hukum berpindahnya hak perwalian wali nasab kepada wali hakim (KUA), dan berikut adalah sebab-sebab jatuhnya perwalian kepada wali hakim yang terdapat dalam beberapa referensi Hadis, Kitab para ulama Salafi, dan beberapa referensi lainnya, berikut penjelasannya: (1) Wali Nasab Gaib (Wali yang Ada tidak Memenuhi Syarat). Bagi calon mempelai wanita yang tidak mempunyai wali nasab seperti saudara kandung, maka wali hakimlah yang menjadi wali dalam perkawinannya.

Asqalani (t.t.:211-212) menyatakan, Nabi SAW. bersabda:

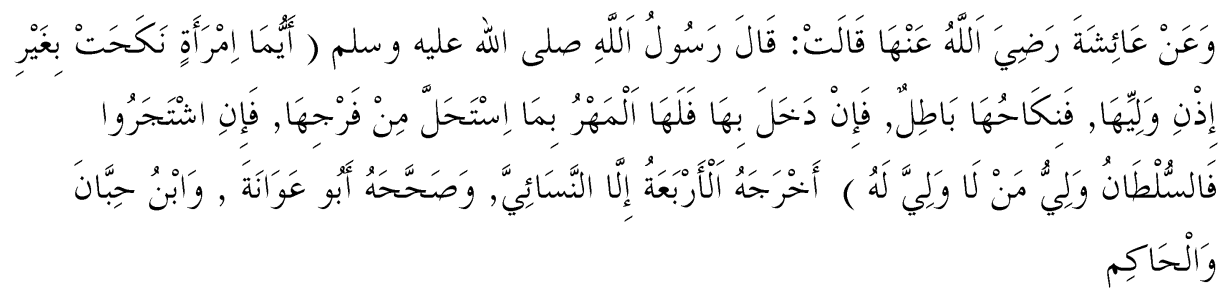

Dari 'Aisyah Radliyallaahu 'anhu bahwa Rasulullah Shallallaahu 'alaihi wa Sallam bersabda: "Perempuan yang nikah tanpa izin walinya, maka nikahnya batil. Jika sang laki-laki telah mencampurinya, maka ia wajib membayar maskawin untuk kehormatan yang telah dihalalkan darinya, dan jika mereka bertengkar maka penguasa dapat menjadi wali bagi wanita yang tidak mempunyai wali." Dikeluarkan oleh Imam Empat kecuali Nasa'i. Hadits shahih menurut Ibnu Uwanah, Ibnu Hibban, dan Hakim (Al-Asqalany, 2008: 1010).

Dalam Islam, apabila wali aqrab (dekat) tidak memenuhi syarat untuk menjadi wali seperti gila, tidak sampai umur (belum baligh) dan sebagainya maka kuasa wali berpindah kepada wali $a b^{\prime} a d$ (jauh). Jika satusatunya wali yang ada juga tidak memenuhi syarat, maka kekuasaan wali berpindah kepada wali hakim.

1) Anak di luar Nikah

Anak diluar nikah adalah anak yang lahir sebelum diadakan pernikahan yang sah. Misalnya jika sepasang laki-laki dan perempuan bersetubuh, kemudian mengandung maka anak yang dikandung itu dianggap anak diluar nikah walaupun anak itu lahir dalam pernikahan yang sah. Jika anak diluar nikah tersebut perempuan dan akan menikah di kemudian hari, maka walinya ialah wali hakim. (Anonimous, t.t.: 93). 


\section{2) Wali Aqrab sedang Menunaikan Haji atau Umrah}

Menurut Nawawi (t.t.: 233) dalam Minhaj al Thalibin, disebutkan jika wali aqrab menunaikan haji atau umrah, maka hak walinya hilang dan hak wali itu juga tidak berpindah kepada wali $a b^{\prime} a d$, akan tetapi hak wali itu berpindah kepada wali hakim. Demikian juga seandainya wali aqrab itu mewakilakan sebelum pergi haji atau umrah, maka wakalah (perwakilan) itu tidak sah.

Rasulullah SAW. bersabda:

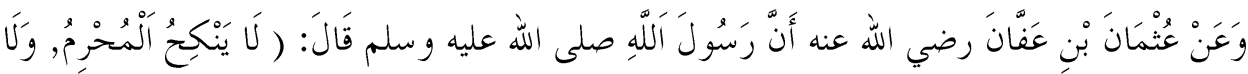

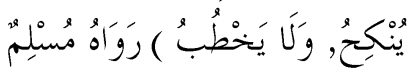

"Dari Utsman Ibnu Affan Radliyallaahu 'anhu bahwa Rasulullah Shallallaahu 'alaihi wa Sallam bersabda: "Orang yang sedang berihram tidak diperbolehkan menikah, menikahkan, dan melamar", HR. Muslim (Asqalani, 2014:273).

Apabila seorang perempuan yang hendak menikah, dan walinya sedang berihram hendaklah menunggu sehingga wali itu pulang dari mekah atau dengan menggunakan wali hakim.

3) Wali 'Adhal

Sabiq (2008: 368) berpendapat "dalam hal 'adhalnya wali, maka perwalian pindah ke tangan hakim". Dalam prakteknya di Indonesia untuk menentukan wali 'adhal yaitu melalui prosedur penetapan adhal-nya wali dari Pengadilan Agama untuk menentukan dibenarkan tidaknya alasan penolakan dari wali, karena jika alasannya benar dan dibenarkan dalam persidangan di pengadilan maka perwaliannya tidak berpindah kepada orang lain karena ia dianggap tidak adhal/ menghalangi.

\section{METODE PENELITIAN}

Jenis penelitian ini adalah penelitian kualitatif dengan metode deskriptif. Penelitian ini berusaha memecahkan masalah dengan menggambarkan problematika yang terjadi. Hal ini didasarkan pada pertimbangan bahwa peneliti ingin memahami, mengkaji secara mendalam serta memaparkannya dalam tulisan ini mengenai wali hakim, tentang bagaimana wali hakim berperan sebagai pengganti wali dalam perkawinan, yang disebabkan oleh beberapa faktor, maka relevan jika penelitian ini dilakukan dengan menggunakan pendekatan kualitatif 


\section{HASIL PENELITIAN DAN PEMBAHASAN}

\section{Hukum Wali Hakim dalam Kompilasi Hukum Islam}

Dalam Kompilasi Hukum Islam dinyatakan tentang hukum wali hakim dalam pernikahan, yaitu pasal 19 dan 20 sebagai berikut: Pasal 19: Wali nikah dalam perkawinan merupakan rukun yang harus dipenuhi bagi calon mempelai wanita yang bertindak untuk menikahkannya. Pasal 20: (1) Yang bertindak sebagai wali nikah ialah seorang laki-laki yang memenuhi syarat hukum Islam yakni muslim, aqil dan baligh. (2) (2) Wali nikah terdiri dari: a. Wali nasab; b. Wali hakim (Anonimous, 2007:11).

Keberadaan wali nikah dalam pernikahan adalah suatu hal yang harus ada, tidak sah akad nikah apabila tidak disertai wali. Dalam perkawinan, wali ditempatkan sebagai rukun nikah menurut kesepakatan ulama secara prinsip. Dalam akad perkawinan itu sendiri, wali mempunyai tugas sebagai orang yang mengucapkan ijab nikah yang kemudian dilanjutkan pengucapan kabul dari calon mempelai laki-laki. Mengenai tugas wali pada akad pernikahan, dalam Kompilasi Hukum Islam pasal 28 dan 29 diuraikan sebagai berikut: Pasal 28: Akad nikah dilaksanakan sendiri secara pribadi oleh wali nikah yang bersangkutan. Wali nikah mewakilkan kepada orang lain. Pasal 29: (1) Yang berhak mengucapkan kabul ialah calon mempelai pria secara pribadi. (2) Dalam hal-hal tertentu ucapan kabul nikah dapat diwakilkan kepada pria lain sengan ketentuan calon mempelai pria memeberi kuasa yang tegas secara tertulis bahwa penerimaan wakil atas akad nikah itu adalah untuk mempelai pria. (3) Dalam hal calon mempelai wanita atau wali keberatan calon mempelai pria diwakili,maka akad nikah tidak boleh dilangsungkan (Anonimous, 2007:13-14).

Namun demikian mengenai sahnya suatu akad pernikahan, maka segala sesuatu yang berkaitan dengan akad pernikahan harus dipenuhi, salah satunya yaitu adanya wali. Mengenai perlunya wali dalam menentukan sahnya akad nikah, menurut Aziz (2009:38) dalam Qowaid Fiqhiyyah menyatakan:

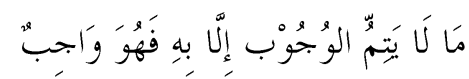

"Sesuatu yang wajib tidak sempurna kecuali dengannya, maka sesuatu itu hukumnya wajib juga".

Sesuai dengan kaidah diatas, dapat diambil kesimpulan mengenai pentingnya wali dalam sahnya akad nikah, maka akad nikah tidak akan sah apabila tidak disertai wali, karena akad nikah adalah sesuatu yang wajib. Maka wali juga menjadi hukum wajib karenanya.

Dasar hukum begitu pentingnya wali dalam pernikahan, Asqalani (t.t.:211) menerangkan, Nabi SAW. bersabda, yaitu: 


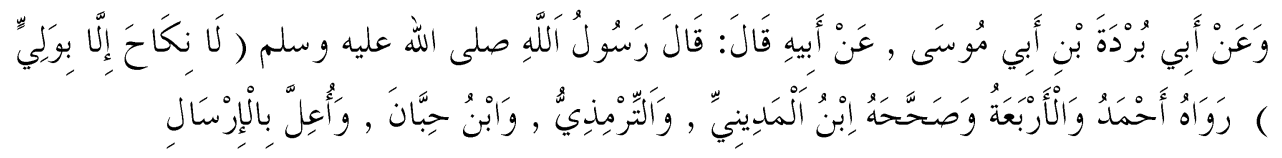

Dari Abu Burdah Ibnu Abu Musa, dari ayahnya Radliyallaahu 'anhu bahwa Rasulullah Shallallaahu 'alaihi wa Sallam bersabda: "Tidak sah nikah kecuali dengan wali." Riwayat Ahmad dan Imam Empat. Hadits shahih menurut Ibnu al-Madiny, Tirmidzi, dan Ibnu Hibban. Sebagian menilainya hadits mursal (Al-Asqalani, 2008:1008).

Hadis diatas adalah hadis yang menghukumi tentang pentingnya wali, yaitu tidak sah nikah tanpa adanya wali. Seseorang yang hendak menikah namun tidak terpenuhi rukun dan syaratnya, akan berakibat tidak sah akad nikahnya. Rukun-rukun dan syarat-syarat pernikahan adalah mutlak adanya. Meskipun dalam kaitan hal ini terdapat hadis tentang pernikahan bagi wanita janda, yaitu jika janda akan dinikahkan lagi harus ada izin darinya, tidak boleh wali memaksa menikah bagi janda, namun bukan berarti dibolehkan pernikahannya tanpa adanya wali, karena akad nikahnya apabila seperti itu adalah batil.

Rasjid (2005:383) menerangkan yang dianggap sah untuk menjadi wali mempelai perempuan ialah menurut susunan yang akan diuraikan dibawah ini, karena wali-wali itu memang telah diketahui oleh orang yang ada pada masa turun ayat: "Janganlah kamu menghalangi mereka menikah". (Al-Baqarah:232). Begitu juga Hadis Ummu Salamah yang telah berkata kepada Rasulullah, "Wali saya tidak ada seorangpun yang dekat".

Selanjutnya Rasjid (2005:383) menyatakan semua itu menjadi tanda bahwa wali-wali itu telah diketahui (dikenal), yaitu:

1) Bapaknya,

2) Kakeknya (Bapak dari bapak mempelai perempuan),

3) Saudara laki-laki yang sebapak seibu dengannya,

4) Saudara laki-laki yang sebapak saja dengannya,

5) Anak laki-laki dari saudara laki-laki yang seibu sebapak dengannya,

6) Anak laki-laki dari saudara laki-laki yang sebapak saja dengannya,

7) Saudara bapak yang laki-laki (paman dari pihak bapak),

8) Anak laki-laki pamannya dari pihak bapaknya,

9) Hakim.

Dalam Undang-Undang No.1 Tahun 1974 tentang Perkawinan (Anonimous, 2003:4) pasal 6 menerangkan tentang perwalian (orang tua) dalam hal pernikahan berperan sebagai pihak yang mengizinkan mempelai 
yang usianya kurang dari 21 tahun. Sehingga dengan ketentuan ini, mempelai yang sudah berumur 21 tahun tidak perlu meminta izin untuk melakukan pernikahan. Dalam Undang-Undang ini tidak diatur lebih lanjut mengenai perwalian nikah, dapat berakibat sah atau tidak. Berbeda dalam Kompilasi Hukum Islam yaitu penting adanya wali dalam setiap pernikahan, apabila tidak ada maka akad nikahnya tidak sah.

Peran dan Fungsi Wali Hakim dalam Kompilasi Hukum Islam

Dalam Kompilasi Hukum Islam pasal 23 dijelaskan, sebagai berikut: Pasal 23: (1) Wali hakim baru dapat bertindak sebagai wali nikah apabila wali nasab tidak ada atau tidak mungkin menghadirkannya atau tidak diketahui tempat tinggalnya atau gaib atau adlal atau enggan. (2) Dalam hal wali adlal atau enggan maka wali hakim baru dapat bertindak sebagai wali nikah setelah ada putusan Pengadilan Agama tentang wali tersebut (Anonimous, 2007:11).

Pasal yang dicantumkan diatas adalah pasal dalam Kompilasi Hukum Islam yang berkenaan dengan alasan elementer timbulnya kewajiban hukum wali nikah kepada wali hakim. Penjelasan berpindahnya hak perwalian kepada wali hakim dalam pasal diatas adalah sebagai berikut:

1) Wali Nasab Gaib (Tidak Ada)

Syarbini (t.t.:413) dalam Al Iqna menerangkan bahwa "Hakim menikahkan karena tidak ada wali baik itu terhalang jarak meskipun yang pendek atau sedang ihram". Namun dalam masa ini sangat tidak dimungkinkan seorang wali tidak ada pada saat pernikahan anak-anaknya, meskipun ketika wali itu sedang berihram maka calon pengantin dalam kebudayaan di Indonesia akan menunggu kedatangan wali nasab dari tanah suci, baru kemudian melaksanakan akad pernikahan.

Demikian pula seperti keterangan diatas, menurut keterangan Imam Nawawi (t.t.:233) dalam Minhaj at Thalibin yang tercantum dalam bab nikah bahwa jika wali aqrab menunaikan haji atau umrah, maka hak walinya hilang dan hak wali itu juga tidak berpindah kepada wali $a b^{\prime} a d$, akan tetapi hak wali itu berpindah kepada wali hakim. Namun seandainya wali aqrab itu mewakilkan akad nikah sebelum pergi haji atau umrah, maka wakalah itu tidak sah. Karena apabila wakalah sama pula hukumnya dengan wali nasab yang menikahkan, hanya saja terwakili oleh orang lain.

Rasulullah SAW. bersabda:

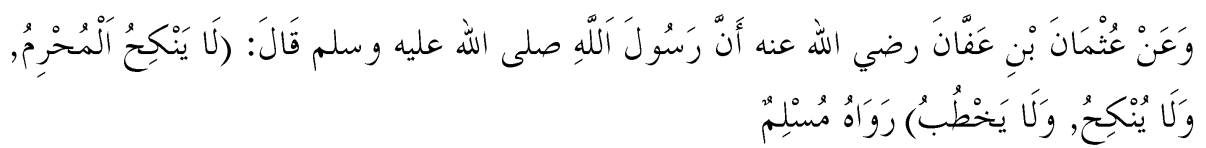


"Dari Utsman Ibnu Affan Radliyallaahu 'anhu bahwa Rasulullah Shallallaahu 'alaihi wa Sallam bersabda: "Orang yang sedang berihram tidak diperbolehkan menikah, menikahkan, dan melamar", HR. Muslim (Asqalani, 2014:273).

\section{2) Masyakah dalam Menghadirkan Wali Nasab}

Kondisi wali nikah dalam permasalahan ini kemungkinan besar wali nikah (yang dimaksud adalah wali aqrab) sedang berada di tempat yang jauh, diketahui tempatnya, akan tetapi tidak bisa dipastikan akan kehadirannya pada pernikahan. Setelah itu tidak serta merta hak perwalian nikah wali dekat jatuh kepada wali yang jauh, apabila wali aqrab tersebut masih memiliki syarat-syarat yang harus dimiliki seorang wali.

Syarat-syarat wali nikah yang dimaksud diatas menurut Imam Taqiyudin dalam Kifayatul Akhyar, menyatakan bahwa:

Wali dan dua orang saksi membutuhkan kepada enam syarat, yaitu: Islam, baligh, mempunyai akal sempurna, merdeka dari perbudakan, laki-laki dan bersifat adil kecuali sesungguhnya tidak membutuhkan nikahnya wanita dzimmi pada wali yang muslim dan tidak pula nikahnya hamba sahaya perempuan kepada adil tuannya. ( Taqiyudin, t.t. juz 2:40-41)

\section{3) Tidak Diketahui Tempat Tinggal Wali Nasab}

Tempat tinggal yang dimaksud adalah rumah berdiam diri wali nikah untuk melakukan aktivitas sehari-hari. Tidak diketahui tempat tinggalnya berarti wali nikah tidak memberitahukan kepada anak dibawah perwaliannya dan atau juga yang berada di bawah perwaliannya tidak mencari atau tidak dapat mencari tempat tinggal wali tersebut. Namun sebelum diadakannya akad nikah, ikhtiar untuk mencari alamat rumah wali harus diusahakan, supaya benar-benar dipastikan bahwa alamat tempat tinggal wali memang tidak diketahui. Setelah itu barulah muncul kebolehan untuk menggunakan wali hakim. Sesuai dengan kaidah fikih (Mudjib, 1996:29), yaitu:

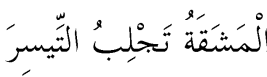

“Kesulitan menarik adanya kemudahan".

4) Wali Nasab 'Adhal

Wali 'adhal atau wali nasab yang enggan menikahkan anaknya, padahal tidak memiliki alasan yang dapat diterima, oleh karena itu perempuan yang ada dibawah perwaliannya dapat mengajukan permohonan untuk wali hakim. Dengan demikian hak kewaliannya tidak 
jatuh kepada wali-wali yang urutannya dibawahnya tetapi langsung kepada wali hakim. Jadi wali yang enggan mengawinkan anak di bawah perwaliannya tanpa alasan-alasan yang dapat diterima disebut dengan wali 'adhal atau wali yang enggan. Hal ini karena pada prinsipnya para wali tidak boleh menghalangi perkawinan anak dibawah perwaliannya tanpa alasan-alasan yang prinsipal, tidak boleh mencegah kalau sesuatunya memang normal, dan tidak boleh menyakiti anak dibawah perwaliannya.

Syarbini (t.t.:413) menerangkan bahwa "Begitu pula hakim menikahkan ketika wali nasab aqrab tidak mau menikahkan meskipun dia itu wali mujbir, dan perwalian tidak berpindah dari wali aqrab kepada wali $a b^{\prime} a d$ ketika 'adhal-nya wali kurang dari tiga kali. Maka apabila lebih dari tiga kali wali $a b^{\prime} a d$ menikahkan untuk mencegah perwalian fasiq seperti yang diriwayatkan Bukhari dan Muslim".

Tentang 'adhal-nya wali, Allah berfirman:

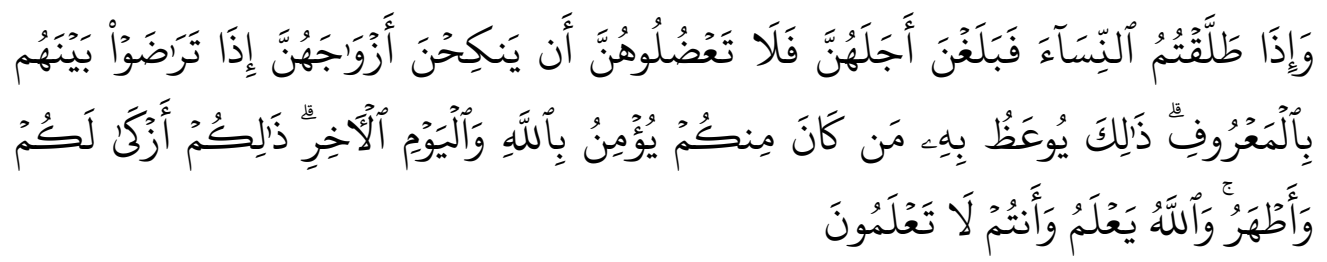

"Apabila kamu mentalak isteri-isterimu, lalu habis masa iddahnya, Maka janganlah kamu (para wali) menghalangi mereka kawin lagi dengan bakal suaminya, apabila telah terdapat kerelaan di antara mereka dengan cara yang ma'ruf" (Al Baqarah, 2:232).

Dalam ayat diatas dapat diambil hukum bahwa jika ada wali nasab aqrab yang tidak mau menikahkan maka hukumnya tidak boleh, karena termasuk menghalang-halangi untuk berbuat ibadah yaitu menikah. Dalam konteks hukumnya di Indonesia apabila terjadi wali 'adhal maka para pihak dalam hal ini calon mempelai atau pihak dari calon mempelai mengajukan gugatan wali kepada Pengadilan Agama daerah hukum masing-masing pihak (penggugat dan tergugat). Baru setelah disidangkan, apabila memang wali nasab tidak mau menikahkan tanpa alasan (terkecuali alasan syariat), hakim akan memutuskan hak perwalian jatuh kepada wali hakim (Pegawai Nikah dari KUA). Namun apabila wali nasab kemudian rida dan membolehkan para calon mempelai untuk menikah, maka hak wali nikah tetap berada pada wali nasab.

Asqalani (t.t.:212) menyatakan, Nabi SAW. bersabda:

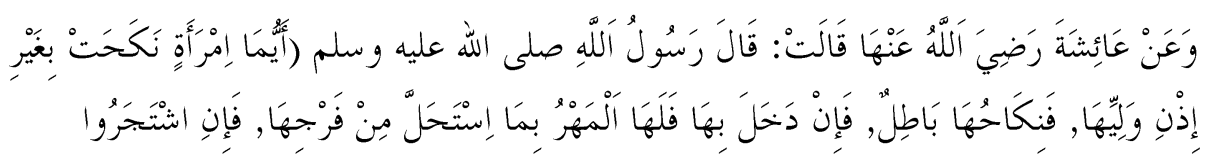




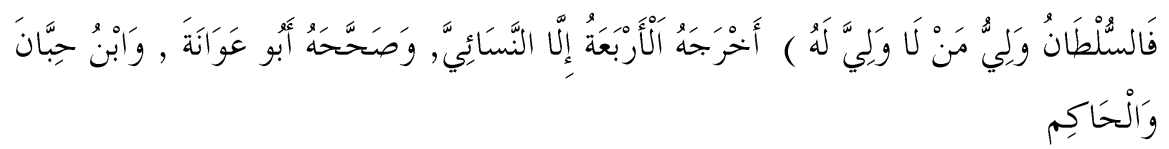

Dari 'Aisyah Radliyallaahu 'anhu bahwa Rasulullah Shallallaahu 'alaihi wa Sallam bersabda: "Perempuan yang nikah tanpa izin walinya, maka nikahnya batil. Jika sang laki-laki telah mencampurinya, maka ia wajib membayar maskawin untuk kehormatan yang telah dihalalkan darinya, dan jika mereka bertengkar maka penguasa dapat menjadi wali bagi wanita yang tidak mempunyai wali." Dikeluarkan oleh Imam Empat kecuali Nasa'i. Hadits shahih menurut Ibnu Uwanah, Ibnu Hibban, dan Hakim (Asqalani, 2011:247).

\section{Peran Wali Hakim sebagai Wali Nikah Pengganti Wali Nasab}

Menurut Rofiq (1997:88), peran pokok wali hakim yaitu perpindahan tugas wali nasab kepada wali hakim dalam menikahkan yang disebabkan oleh beberapa hal diantaranya wali aqrab atau wali ab'ad tidak ada sama sekali, wali aqrab menjadi calon mempelai pria, sedang berihram, menderita sakit yang sedang kritis, tidak diketahui tempat tinggalnya (mafqud).

Sabiq (2008:370) menjelaskan jika wali aqrab dipenjara dan tidak memungkinkan untuk menghadirkannya walaupun jaraknya dekat maka ia dianggap jauh, demikian pula jika wali dekat tidak diketahui alamatnya walaupun dekat letak tempat tinggalnya.

Hakim (2000:65) menerangkan dalam hal wali aqrab gaib, tidak ada di tempat dan atau tidak diketahui keberadaannya Hanafi berpendapat bahwa perwalian kepada urutan selanjutnya (wali $a b^{\prime} a d$ ) dan suatu saat wali aqrab datang, dia tidak dapat membatalkan pernikahan tersebut karena kegaibannya sama dengan ketiadaannya demikian juga Malik. Sedangkan Syafi'i berpendapat bahwa perwaliannya pindah ke hakim.

Begitu pula dengan beberapa alasan diatas, wali hakim juga menjadi wali nikah bagi "anak diluar nikah". Anak diluar nikah adalah anak yang lahir sebelum diadakan pernikahan yang sah. Misalnya jika sepasang laki-laki dan perempuan bersetubuh, kemudian mengandung maka anak yang dikandung itu dianggap anak diluar nikah walaupun anak itu lahir dalam pernikahan yang sah. Jika anak diluar nikah tersebut perempuan dan akan menikah di kemudian hari, maka walinya ialah wali hakim (Anonimous, t.t.: 93).

Begitu juga anak angkat, walinya adalah wali hakim karena anak itu dianggap tidak mempunyai wali nasab. Kecuali jika anak angkat tersebut diketahui ayahnya yang sah atau keluarga yang sah, maka walinya ialah berdasarkan susunan atau tertib wali yang ada, bukan ayah angkat. Oleh karena itu, para orang tua atau ayah angkat hendaklah berhati-hati dalam 
masalah ini, jangan menyembunyikan keadaan yang sebenarnya (Anonimous, t.t.: 94).

Jazairi (2012:575) menerangkan wali mempunyai sejumlah hukum yang wajib ada: pertama, ia layak menjadi wali yaitu laki-laki, balig, berakal sempurna, dan orang merdeka (bukan budak); kedua, orang yang hendak menikahi seorang wanita harus meminta izin kepada walinya jika wanita tersebut gadis dan walinya adalah ayahnya sendiri; ketiga, perwalian wali yang dekat tidak sah dengan keberadaan wali yang lebih dekat. Jadi tidak sah perwalian saudara ayah dengan keberadaan saudara kandung; keempat, jika seorang wanita meminta dua orang dari kerabatnya menikahkan dirinya, kemudian masing-masing dari keduanya menikahkannya dengan orang lain, maka wanita tersebut menjadi istri laki-laki yang lebih dulu dinikahkan dengannya, dan jika akad dilakukan pada waktu yang sama maka pernikahan wanita tersebut batal.

Wali merupakan salah satu rukun nikah, maka tidak sah nikah kecuali harus ada walinya. Firman Allah "Apabila kamu mentalak isteriisterimu, lalu habis masa iddahnya, maka janganlah kamu (para wali) menghalangi mereka kawin lagi dengan bakal suaminya, apabila telah terdapat kerelaan di antara mereka dengan cara yang ma'ruf" (Q.S. Al baqarah, 2:232).

Dalam pembahasannya ayat diatas memang menerangkan pelarangan bagi orang enggan menikahkan tanpa alasan yang jelas, hal ini tentu memberikan pengertian bahwa ketika wanita yang berada di bawah perwalian seorang wali baik itu wali mujbir (ayah dan kakek) ataupun ashabah-nya, ketika wanita tersebut akan menikah dan saling suka antara wanita dan calon suaminya maka wali tidak boleh menghalangi mereka untuk melakukan perkawinan (adhal) kecuali ada alasan yang bersifat syari'at seperti beda agama, tidak sekufu atau perbedaan karena budak dan orang merdeka. Tentang pelarangan pada setiap nash al Qur'an ada kaidah ushuliah, yaitu:

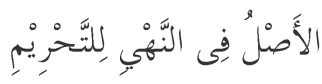

"Hukum asal dalam larangan adalah haram".

Selain beberapa hal yang telah dijelaskan, ayat diatas juga mengindikasikan bahwa perkawinan erat kaitannya dengan wali. Sehingga apabila wanita akan menikah maka harus ada persetujuan dari wali, lebih jauh lagi bahwa wali adalah yang mengucapkan ijab dalam akad pernikahan, salah satu rukun yang akan menentukan sah atau tidaknya suatu pernikahan.

Tentang adanya wali dalam pernikahan Asqalani (t.t.:211) menerangkan bahwa Nabi SAW. bersabda, yaitu: 


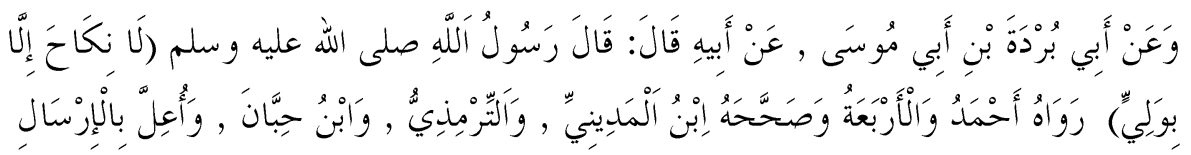

Dari Abu Burdah Ibnu Abu Musa, dari ayahnya Radliyallaahu 'anhu bahwa Rasulullah Shallallaahu 'alaihi wa Sallam bersabda: "Tidak sah nikah kecuali dengan wali." Riwayat Ahmad dan Imam Empat. Hadits shahih menurut Ibnu al-Madini, Tirmidzi, dan Ibnu Hibban. Sebagian menilainya hadits mursal (Al-Asqalani, 2008:1008).

Hadis diatas mengisyaratkan hukum yang umum dalam pernikahan, yaitu tidak sah nikah tanpa adanya wali. Terdapat pula mafhum mukhalafah-nya adalah setiap pernikahan yang ingin sah, maka nikahnya harus disertai wali.

Asqalani (t.t.:211-212) menyatakan, Nabi SAW. bersabda:

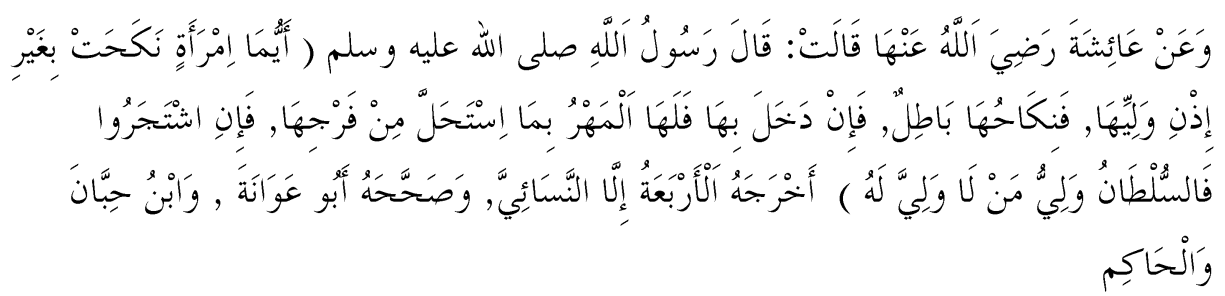

Dari 'Aisyah Radliyallaahu 'anhu bahwa Rasulullah Shallallaahu 'alaihi wa Sallam bersabda: "Perempuan yang nikah tanpa izin walinya, maka nikahnya batil. Jika sang laki-laki telah mencampurinya, maka ia wajib membayar maskawin untuk kehormatan yang telah dihalalkan darinya, dan jika mereka bertengkar maka penguasa dapat menjadi wali bagi wanita yang tidak mempunyai wali." Dikeluarkan oleh Imam Empat kecuali Nasa'i. Hadits shahih menurut Ibnu Uwanah, Ibnu Hibban, dan Hakim. (Al-Asqalani, 2008:1010)

Dalam redaksi hadis diatas terdapat kalimat "Jika mereka bertengkar maka penguasa dapat menjadi wali bagi wanita yang tidak mempunyai wali" hal ini memberi pengertian terhadap wali adhal dan wali nasab yang gaib (tidak ada). Hadis-hadis menjadi dalil bahwa wanita yang menikah harus disertai wali, sampai akhirnya meskipun wali tersebut adalah wali hakim. Maka tidak boleh wanita menikahkan diri sendiri, tentang hal ini Rasulullah SAW. bersabda:

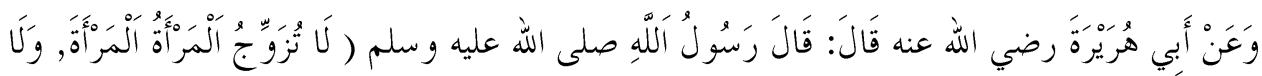

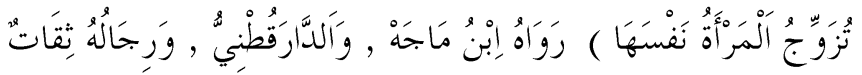

Dari Abu Hurairah Radliyallaahu 'anhu bahwa Rasulullah Shallallaahu 'alaihi wa Sallam bersabda: "Perempuan tidak boleh menikahkan perempuan lainnya, dan tidak boleh pula menikahkan dirinya." HR. 
Ibnu Majah dan Daruquthni dengan perawi-perawi yang dapat dipercaya (Asqalani, 2014:272).

Bahkan menurut Imam Taqiyudin (t.t.:48) hadis diatas ditambah dengan redaksi:

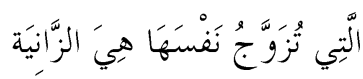

"Siapa saja wanita yang menikahkan dirinya sendiri, maka dia (wanita) adalah pezina".

Jenis-jenis wali dalam Islam terbagi dari dua, yaitu wali nasab dan wali hakim. Wali nasab sebagaimana dijelaskan dalam Kompilasi Hukum Islam, adalah sebagai berikut: Pasal 20: (1) Yang bertindak sebagai wali nikah ialah seorang laki-laki yang memenuhi syarat hukum Islam yakni muslim, aqil dan baligh. (2) Wali nikah terdiri dari: a. Wali nasab; b. Wali hakim. Pasal 21: (1) Wali nasab terdiri dari empat kelompok dalam urutan kedudukan, kelompok yang satu didahulukan dan kelompok yang lain sesuai erat tidaknya susunan kekerabatan dengan calon mempelai wanita. Pertama, kelompok kerabat laki-laki garis lurus keatas yakni ayah, kakek dari pihak ayah dan seterusnya. Kedua, kelompok kerabat saudara lakilaki kandung atau saudara laki-laki seayah, dan keturunan laki-laki mereka. Ketiga, kelompok kerabat paman, yakni saudara laki-laki kandung ayah, saudara seayah dan keturunan laki-laki mereka. Keempat, kelompok saudara laki-laki kandung kakek, saudara laki-laki seayah dan keturunan laki-laki mereka (Anonimous, 2007:12).

Pengertian pasal KHI diatas adalah bagian dari urutan tertib wali nasab yang ada dalam hukum positif umat Islam Indonesia. Imam Taqiyudin (t.t.: 52) menerangkan bahwa "Apabila ada wali yang menikahkan berbeda dengan urutan tertib wali yang telah ada maka nikahnya tidak sah". Hal ini memberikan pemahaman pula bahwa perwalian wali dekat (yang berhak menikahkan) tidak akan jatuh pada wali jauh (menerima hak wali nikah dari wali dekat) apabila syarat-syarat yang ada pada wali dekat masih ada. Oleh karena itu wali jauh berhak menikahkan apabila telah hilang salah satu syarat wali pada wali dekat.

Kemudian wali nikah yang selanjutnya adalah wali hakim, dalam Kompilasi Hukum Islam, dijelaskan sebagai berikut: Pasal 1b: Wali hakim ialah wali nikah yang ditunjuk oleh Menteri Agama atau pejabat yang ditunjuk olehnya, yang diberi hak dan kewenangan untuk bertindak sebagai wali nikah". Pasal 23: (1) Wali hakim baru dapat bertindak sebagai wali nikah apabila wali nasab tidak ada atau tidak mungkin menghadirkannya atau tidak diketahui tempat tinggalnya atau gaib atau adlal atau enggan. (2) Dalam hal wali adlal atau enggan maka wali hakim 
baru dapat bertindak sebagai wali nikah setelah ada putusan Pengadilan Agama tentang wali tersebut (Anonimous, 2007:12).

Tentang peran wali nikah, ada dua hal yang akan dibahas pula yaitu perwalian bagi anak diluar nikah dan wali bagi perempuan janda berikut pembahasannya: Pertama, anak di luar nikah. Menurut Imam Syafi'i, Imam Malik dan kawan-kawan, apabila salah seorang laki-laki mengawini seorang perempuan yang belum pernah dikumpulinya atau sudah pernah, maka bila waktu kurang dari enam bulan dari akad perkawinannya perempuan tersebut melahirkan anak (bukan dari masa berkumpulnya), anak yang dilahirkannya itu tidak dapat dipertalikannya nasabnya kepada seorang laki-laki yang menyebabkan perempuan itu mengandung. Perhitungan enam bulan ini dihitung dari waktu berkumpul. Sedangkan Imam Abu Hanifah memilih akad nikah sebagai dasar perhitungan enam bulan tersebut dimana konsekuensinya ketika anak tersebut lahir kurang dari enam bulan di hitung dari akad nikah maka anak itu tidak bisa dipertalikan nasab kepada ayahnya (Ghofar, 2000:46-47).

Ghofar (1996:83) menerangkan bahwa menurut Imam AsySyaukani dalam kitab Nailul Awthar, perselisihan ulama dalam menetapkan status anak hasil perzinahan itu karena mereka berbeda dalam mengartikan kata firasy yang terdapat pada hadis yang diriwayatkan oleh jama'ah ahli hadis. Hadis tersebut adalah sebagai berikut:

$$
\begin{aligned}
& \text { عن ابي هريرة رضي الله عنه قال: قال رسول الله صلى الله عليه وسلم الولد للفراش وللعاهر }
\end{aligned}
$$

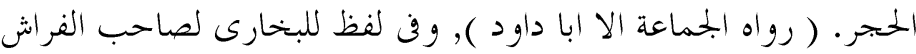

"Anak (hasil zina) adalah milik orang yang seranjang (seketiduran) dan bagi pezina adalah hukuman rajam (HR. Jama'ah kecuali Abu Daud), dan dalam keterangan Bukhari anak zina adalah bagi pemilik tikar"

Imam Syafi'i dan Imam Malik berpendapat bahwa wajah istidlal atau segi penunjukan dalil dari kata firasy yang tersebut dalam hadis diatas ialah bermakna ibu, sehingga nasab anak hasil perzinahan itu hanya kembali kepada ibunya saja. Pendapat mereka itu juga di analogikan dengan ketentuan jumlah minimal bagi wanita hamil yakni anak yang lahir kurang dari enam bulan sejak saat berkumpulnya suami istri tanpa memperhatikan pernikahan, maka anak yang lahir tersebut akan dinasabkan kepada ibunya saja.

Berbeda dengan Abu Hanifah, beliau disamping berpegang teguh kepada yuridis formil yakni keabsahan anak sebagai keluarga ayah dilihat dari masa lahirnya tidak kurang dari jangka waktu enam bulan terhitung sejak pernikahan ibu dengan ayahnya. Di samping itu, beliau juga mengambil wajah istidlal dari kata firasy ialah menunjukkan kepada laki-laki, pendapat ini berdasarkan sebuah hadis dari Abu Hurairah yaitu; 


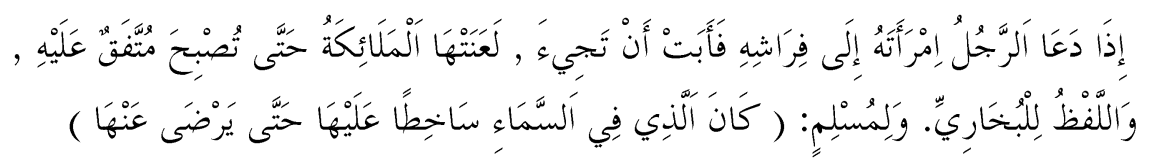

Apabila seorang suami mengajak istrinya ke tempat tidur, tapi ia menolak untuk datang, lalu sang suami marah sepanjang malam, maka para malaikat melaknatnya (sang istri) hingga datang pagi." Muttafaq Alaihi dan lafadznya menurut Bukhari. Menurut riwayat muslim disebutkan, "Yang ada dilangit murka kepadanya hingga suaminya memaafkannya.

Menurut Shan'ani (1994:172-173) “Dalam kondisi seperti ini maka yang akan menjadi wali bagi anak tersebut adalah sulthan atau wali hakim. As-Syaikh ibnu 'Usaimin rahimahullahu berkata dalam As-Syarhul Mufti bahwa yang dimaksud dengan Sulthan adalah imam (amir) atau perwakilannya". Apabila di Indonesia mereka adalah petugas (penghulu) Kantor Urusan Agama (KUA). Pendapat ini yang menyatakan bahwa wali bagi anak zina adalah sulthan.

Mukhtar (1993:96) menerangkan pula bahwa Syeikh Shan'ani berkata dalam Subulus Salam: hadis ini menunjukkan bahwa sulthan adalah wali bagi seorang wanita yang tidak mempunyai wali dalam pernikahan, baik karena memang tidak ada walinya atau walinya ada tetapi tidak mau menikahkannya. Apabila kita melihat kasus diatas maka anak perempuan tersebut termasuk dalam perempuan yang tidak mempunyai wali karena anak tersebut tidak bisa dinasabkan kepada ayahnya sehingga nasabnya tersebut hanya dibangsakan kepada ibu. Dengan hanya dinasabkan kepada pihak ibu, akan tetapi bukan berarti hal ini membenarkan bahwa ibu bisa menjadi wali terhadap anak perempuan tersebut, karena wanita tidak boleh menjadi wali dan tidak boleh menikahkan diri sendiri.

Kedua, wali nikah bagi wanita janda. Nabi Muhammad SAW bersabda:

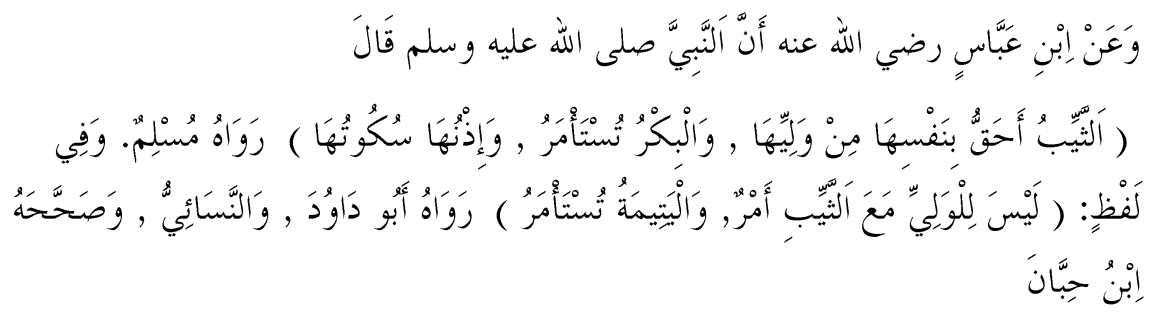

Dari Ibnu Abbas bahwa Nabi Shallallaahu 'alaihi wa Sallam bersabda: "Seorang janda lebih berhak menentukan (pilihan) dirinya daripada walinya dan seorang gadis diajak berembuk, dan tanda izinnya adalah diamnya." Riwayat Imam Muslim. Dalam lafaz lain disebutkan, "Tidak ada perintah bagi wali terhadap janda, dan anak yatim harus diajak 
berembuk." Riwayat Abu Dawud dan Nasa'i. Hadits shahih menurut Ibnu Hibban (Asqalani, 2014:271).

Syarbini (t.t.:415) menerangkan tentang janda, bahwa janda yang sudah balig tidak boleh dan tidak sah menikahkannya, meskipun keperawanannya telah kembali kecuali ada izin darinya, karena hadis. Alasannya adalah bahwa janda telah mengetahui maksud dari nikah maka janganlah dipaksa, berbeda dengan perawan.

Selanjutnya Syarbini (t.t.:415) juga menerangkan apabila janda yang masih kecil tidak gila dan bukan amat janganlah dinikahkan meskipun sudah pantas berhubungan ataupun tidak kecuali setelah mencapai balig dan ada izin darinya, karena izin ketika wanita tersebut masih kecil itu tidak kuat, maka haruslah dicegah menikahkannya sampai balig. Adapun anak kecil yang hilang akal maka harus dinikahkan oleh ayah atau kakeknya sebelum mencapai balig demi kemaslahatan, dan bagi amat (hamba sahaya perempuan) maka bagi tuannya untuk menikahkannya, dan begitupula tuan yang menjadi wali untuk menciptakan kemaslahatan.

\section{Produk Hukum Wali Nasab dan Wali Hakim dalam Islam}

Dari berbagai penjelasan mengenai wali nikah diatas, maka dapat diuraikan pokok hukumnya kedalam beberapa hukum taklifi, yaitu sebagai berikut: Pertama, hukum wajib, yaitu: (1) Wali nikah adalah pokok utama (rukun) dalam pernikahan, tanpa adanya wali maka pernikahan tidak akan sah. (2) Wali nikah tidak akan berpindah dari wali dekat kepada wali jauh, kecuali telah hilang syarat-syaratnya meskipun hanya satu. Apabila wali jauh tidak ada maka perwalian jatuh kepada wali hakim. (3) Telah sepakat para ulama sesungguhnya wanita yang tidak mempunyai wali, maka hakimlah yang menjadi wali baginya, kemudian wali hakim menikahkan kepada laki-laki yang disukai yang akan dinikahi perempuan itu.

Kedua, hukum mubah (boleh). Qathan (2004:6) dalam Al Iqna fi Masaail al Ijma' menerangkan sebagai berikut: (1) Boleh seorang laki-laki untuk mengakadkan anaknya, baik itu wanita yang masih kecil ataupun sudah besar, terpaksa atau dengan ridanya karena untuk kemaslahatan. (2) Para ulama telah berkumpul bahwa sesungguhnya orang yang mewakili hukumnya menempati posisi orang yang diwakili dalam menikahkan. (3) Menurut para ahli ilmu, mereka berkata "Apabila ada dua orang wali menikahkan perempuan dalam urusannya maka nikahnya ada pada yang pertama". (4) Telah berijma' para ulama, sesungguhnya pernikahan hamba sahaya laki-laki dan perempuan tanpa izin tuannya adalah batil, kecuali ada izin dari tuannya maka hukumnya boleh.

Ketiga, hukum makruh. Qathan (2004:8-9) menerangkan tentang hukum makruh, yaitu: (1) Tidak ada perbedaan antara para ulama, tentang ayah yang menikahkan anaknya yang janda karena itu tidak boleh, kecuali 
ada ridha dari wanita tersebut. (2) Telah sepakat para ulama, sesungguhnya ayah boleh menikahkan anak perempuannya yang masih kecil meskipun tidak ada izinnya, dan berbeda pendapat para ulama apakah anak yang sudah besar boleh dipaksa menikah atau tidak.

Keempat, hukum haram. Qathan (2004:8-9) menerangkan tentang hukum haram, yaitu: (1) Kami tidak mengetahui orang yang berpendapat "Boleh bagi seorang janda untuk menikah tanpa adanya wali, dan tidak boleh kecuali ada izin dari wali (ashabah)". (2) Daud berkata apabila ada pernikahan perempuan perawan maka harus ada wali, dan apabila janda maka tidak membutuhkan wali, ini berbeda dengan ijma para ulama dan hasil perbedaan pada perempuan yang sudah besar, karena sesungguhnya pada perempuan perawan yang masih kecil tidak ada ikhtilaf didalamnya. (3) Orang kafir tidak bisa menjadi wali kepada anak perempuannya yang muslim. (4) Telah sepakat para ulama, jika ada wali nikah yang merupakan hamba sahaya maka dia tidak bisa menikahkan. (5) Bagi hamba sahaya perempuan, maka yang menikahkannya adalah tuannya, maka ashabah (kerabat laki-laki) perempuan tersebut tidak ada yang menikahkannya, tidak ada yang menggugat antara ahli ilmu dalam hal ini. (6) Para ulama telah sepakat, sesungguhnya dzimmi tidak menikahkan anak perempuannya yang muslim, begitu pula muslim tidak menikahkan anaknya yang dzimmi, kecuali ibnu wahab yaitu boleh bagi muslim menikahkan anaknya yang dzimmi. (7) Telah sepakat orang Islam, sesungguhnya wanita tidak bisa menjadi wali dalam pernikahan, dan tidak ada para ahli ilmu yang menggugat hal ini.

\section{KESIMPULAN}

Dari berbagai ulasan dan pembahasan diatas mengenai peran wali hakim sebagai pengganti wali nasab dalam pernikahan, maka penulis cenderung untuk memaparkannya sebagai berikut, wali hakim menggantikan perwalian nikah bagi wanita yang wali nasabnya (wali dekat dan jauh) sudah tidak ada, kemudian wali nasab yang gaib atau tidak diketahui tempatnya (ukuran perjalanan qashar sholat) sedangkan tidak mewakilkan dan tidak tahu kapan akan kedatangannya, kemudian wali yang enggan menikahkan tanpa adanya alasan yang jelas (alasan syar'i), wali hakim juga menjadi wali nikah bagi anak hasil hubungan zina karena dinasabkan pada ibunya saja, sedangkan wanita tidak bisa menjadi wali. Dalam hal walinya oleh wali hakim, maka harus ada putusan dari Pengadilan Agama. 


\section{DAFTAR PUSTAKA}

Abidin dan Aminuddin. (1999). Figh Munakahat, cet. ke-1. CV. Pustaka Setia: Bandung.

Al-Asqalani, Ibnu Hajar. (2011). Bulughul Maram min Adillatil Ahkam. Penerj. Harun Zen\& Zenal Muttaqin. Jabal: Bandung.

Al-Asqalani, Ibnu Hajar. (t.t.). Bulughul Maram min Adillatil Ahkam. Al Bayan: Surabaya.

Al-Bajuri, Syeikh Ibrahim. (t.t.). Al Bajuri, Juz 2, Pustaka Islam: Indonesia.

Al-Jazairi, Abdul al-Rahman. (2004). Al figh 'ala Madzahibul 'Arba'ah. Dar al Kutub al Ilmiah: Beirut.

Al-Jazairi, Abu Bakr Jabir. (2012). Ensiklopedi Muslim, cet. ke-18, terj. Minhaajul Muslim. PT. Darul Falah: Bekasi

Anonimous. (2003). Undang-Undang Republik Indonesia Nomor 1 Tahun 1974 tentang Perkawinan \& Kompilasi Hukum Islam. Bumi Aksara: Jakarta.

Anonimous. (2007). Himpunan Peraturan Perundang-Undangan tentang Kompilasi Hukum Islam, cet. ke-2. Fokus Media: Bandung.

Aziz, Abdul. (2009). Qowaid Fiqhiyyah, cet. ke-2. Amzah: Jakarta.

Ghazali, Abdul Rahman. (2003). Fiqh Munakahat, cet. ke-3. Kencana: Jakarta.

Hakim, Rahmad. (2000). Hukum Perkawinan Islam, cet. ke-1. Pustaka Setia: Bandung.

Imam Nawawi. (t.t.). Minhaj al Thalibin. Darul Minhaj: Beirut.

Moleong. (2001). Metodologi Penelitian Kulitatif. Remaja Rosdakarya: Bandung.

Mujib, Abdul. (1996). Al Qowaidul Fiqhiyyah (Kaidah-kaidah Ilmu Fikih), cet. ke2. Kalam Mulia: Jakarta.

Rasjid, Sulaiman. (2005). Figh Islam, cet. ke-38. Sinar Baru Algesindo: Bandung.

Rofiq, Ahmad. (1997). Hukum Islam di Indonesia, cet. ke-2, Raja Grafindo Persada: Jakarta.

Sabiq, Sayyid. (2008). Fiqih Sunnah, jil. 3. Cakrawala Publishing: Jakarta.

Saebani, Beni Ahmad. (2001). Fiqh Munakahat (Buku II), cet. ke-6. CV. Pustaka Setia: Bandung.

Taqiyuddin Al Hisni. (t.t.). Kifayatul Akhyar. juz 2, Daarul Ilmi: Surabaya.

Waskito, Purwo. (t.t.). Kamus Lengkap Bahasa Indonesia. Grafika Mulia. 
Zuhdi, Masjfuk. (1990). Pengantar Hukum Syari'ah. CV Haji Masagung: Jakarta. 